\title{
Blood meal sources of wild and domestic Triatoma infestans (Hemiptera: Reduviidae) in Bolivia: connectivity between cycles of transmission of Trypanosoma cruzi
}

Rosio Buitrago ${ }^{1 *}$, Marie-France Bosseno ${ }^{1}$, Stéphanie Depickère ${ }^{2}$, Etienne Waleckx ${ }^{1}$, Renata Salas ${ }^{2}$, Claudia Aliaga², Christian Barnabé ${ }^{1}$ and Simone Frédérique Brenière ${ }^{1}$

\begin{abstract}
Background: Chagas disease is a major public health problem in Latin America. Its etiologic agent, Trypanosoma cruzi, is mainly transmitted through the contaminated faeces of blood-sucking insects called triatomines. Triatoma infestans is the main vector in various countries in South America and recently, several foci of wild populations of this species have been described in Bolivia and other countries. These wild populations are suspected of affecting the success of insecticide control campaigns being carried out in South America. To assess the risk that these T. infestans populations pose to human health, it is helpful to determine blood meal sources.
\end{abstract}

Methods: In the present work, blood meals were identified in various Bolivian wild T. infestans populations and in three specific areas, in both wild and intra-peridomestic populations to assess the links between wild and domestic cycles of T. cruzi transmission. PCR-HDA and sequencing of Cytb gene were used to identify these blood meal sources.

Results and discussion: Fourteen vertebrate species were identified as wild blood meal sources. Of those, the most prevalent species were two Andean endemic rodents, Octodontomys gliroides (36\%) and Galea musteloides (30\%), while humans were the third most prevalent source (18.7\%). Of 163 blood meals from peridomestic areas, more than half were chickens, and the others were generally domestic animals or humans. Interestingly, blood from wild animals was identified in triatomines captured in the peridomestic and domestic environment, and blood from domestic animals was found in triatomines captured in the wild, revealing links between wild and domestic cycles of T. cruzi transmission.

Conclusion: The current study suggests that wild T. infestans attack humans in the wild, but is also able to bite humans in domestic settings before going back to its natural environment. These results support the risk to human health posed by wild populations of $T$. infestans.

Keywords: Blood meal sources, Wild Triatoma infestans, Feeding habits, Chagas disease, Triatomines

\footnotetext{
* Correspondence: rosiob8@gmail.com

${ }^{1}$ IRD, Institut de Recherche pour le Développement, UMR INTERTRYP,

(IRD-CIRAD), Interactions hôtes-vecteurs-parasites-environnement dans les maladies tropicales négligées dues aux trypanosomatidés, 911 Av. Agropolis, Montpellier, cédex 5 34394, France

Full list of author information is available at the end of the article
} 


\section{Background}

In Bolivia and other South American countries, Triatoma infestans (Hemiptera: Reduviidae) is the main vector of Trypanosoma cruzi, the causative agent of Chagas disease [1]. Triatoma infestans is very well adapted to the domestic environment and is the target of large-scale campaigns of vector control based on insecticide spraying. This control strategy was initially proposed considering this species to be almost exclusively domestic, except for small wild foci primarily found in the valleys of Cochabamba in Bolivia [2-4]. However, the discovery of wild populations of T. infestans in other ecoregions such as Bolivian Chaco $[5,6]$ indicates that wild populations of T. infestans in Bolivia are more widely distributed than previously assumed [7-11]. They have even been reported in Argentina, Paraguay and Chile [12-14]. These wild populations could potentially pose a risk to human health. Indeed, they can move from the wilderness to human dwellings [15], where they can occasionally come into contact with humans and/or colonize the intra-peridomiciles, creating a dangerous situation of persistence of man-vector contact.

Haematophagy is an obligatory habit of triatomines. Consequently, wild populations of triatomines are closely related to food availability and therefore the distribution of mammals in nature. Surprisingly, few data exist on blood meal sources and trophic preferences (if any) of wild populations of triatomine species. For wild T. infestans, the only data available deal with populations captured in rocky outcrops in the high valleys of Cochabamba (Bolivia) where they were found to be associated with small rodents of the genera Bolomys and Phyllotis and marsupials of the genus Thylamis [7, 16]. Additionally, in the Andean valleys of La Paz (Bolivia), Buitrago et al. (2010) [8] reported the discovery of wild T. infestans in deep cracks serving as shelters for viscachas (Lagidium viscacia), suggesting that this Andean rodent could be a possible blood meal source of wild $T$. infestans, but without clear evidence. Finally, except for a short note presenting the preliminary data of the current study [17], we are not aware of any studies reporting molecular evidence of wild $T$. infestans blood meal source.

The aim of this study was to use molecular techniques to identify the blood meal sources of wild and domestic populations of $T$. infestans in Bolivia and to assess the risk that wild $T$. infestans pose to human health as well as the links between wild and domestic cycles of transmission of $T$. cruzi.

\section{Methods}

\section{Study area and collection of triatomines}

First, studies investigated wild $T$. infestans captured across three eco regions in the endemic area of domestic T. infestans in Bolivia: [18] Inter Andean Dry Forests,
Prepuna, and Gran Chaco ecoregions [19]. The details of this sample consisting of 618 bugs are shown in Table 1.

The second sample analysed was composed of peridomestic populations captured in three different localities where the above wild populations were analysed. The three localities included the rural areas of Sapini $\left(16^{\circ}\right.$ $\left.48^{\prime} 47^{\prime \prime} \mathrm{S}, 67^{\circ} 42^{\prime} 10^{\prime \prime} \mathrm{W}, 1880 \mathrm{~m}\right)$ and Thago Thago $\left(18^{\circ}\right.$ $0^{\prime} 41.53^{\prime \prime S}, 65^{\circ} 48^{\prime} 32.68^{\prime \prime} \mathrm{W}, 2000 \mathrm{~m}$ ) and the urban periphery of the city of Quillacollo $\left(17^{\circ} 25^{\prime} 22.03^{\prime \prime S}, 66^{\circ}\right.$ $17^{\prime} 30.38^{\prime \prime W}, 2600 \mathrm{~m}$ ). These three areas are located in the Inter-Andean Dry Forests. Sapini is located in the La Paz Department near the Luribay River. Since 2003, the village has been under entomological vigilance by the La Paz Departmental Health Service. Despite vector control based on insecticide spraying every 6 months, this village suffers constant reinfestation. It consists of 30 dwellings surrounded by sedimentary cliffs where we captured wild populations of $T$. infestans. Thago Thago is located in the Potosí Department. It is a very small village with 10 dwellings, near a road and surrounded by high mountains with rocky outcrops infested by wild T. infestans. Quillacollo is located $10 \mathrm{~km}$ from the city of Cochabamba. The area is surrounded by hills and the dwellings are very close to rocky outcrops infested by wild populations of $T$. infestans.

Before starting the entomological study, the research team met the authorities in each area to explain the purpose of the work and to obtain their agreement.

In all cases, wild triatomines were collected using mice-baited adhesive traps [20]. All triatomines caught in the same trap were put in a single tube and transported live to the laboratory. In domestic and peridomestic areas, triatomines were captured by active search and placed in a single tube per site of capture.

\section{Laboratory processing}

The species, sex and stage of the triatomines were determined following the taxonomic keys of Lent \& Wygodzinsky [21]. To determine blood meal sources and for direct assessment of the presence or absence of T. cruzi, abdominal contents were recovered in two ways: i) by abdominal dissection and removal of the entire digestive tract with tweezers, ii) by abdominal pressure to obtain intestinal content after cutting the terminal abdomen when insects had an abundant blood meal. Samples were stored at $-20{ }^{\circ} \mathrm{C}$ until processing.

\section{Molecular characterization of blood meal sources}

DNA extraction from intestinal contents of the digestive tracts was performed with QIAamp DNA mini kit (Qiagen, Courtaboeuf, France) according to the recommended protocol for blood samples, with minor modifications as described by Buitrago et al. (2012) [22]. The blood meal sources were identified with PCR-Heteroduplex 
Table 1 Geographic origin of wild T. infestans in three ecoregions of Bolivia

\begin{tabular}{|c|c|c|c|c|c|c|c|}
\hline \multirow[t]{2}{*}{ Ecoregion** } & \multirow[t]{2}{*}{ Department } & \multirow[t]{2}{*}{ Location code } & \multirow[t]{2}{*}{ Latitude (S) } & \multirow[t]{2}{*}{ Longitude (W) } & \multirow[t]{2}{*}{ Altitude (m) } & \multicolumn{2}{|c|}{ No. of blood meals } \\
\hline & & & & & & Processed & Identified \\
\hline $\mathrm{BSIA}$ & La Paz & SAP & $16^{\circ} 48^{\prime} 47.0^{\prime \prime}$ & $67^{\circ} 42^{\prime} 10.0^{\prime \prime}$ & 1880 & 48 & 17 \\
\hline BSIA & La Paz & $\cos 01$ & $16^{\circ} 49^{\prime} 54.1^{\prime \prime}$ & $67^{\circ} 42^{\prime} 20.6^{\prime \prime}$ & 1905 & 9 & 2 \\
\hline BSIA & Potosi & BSIA & $18^{\circ} 00^{\prime} 43.0^{\prime \prime}$ & $65^{\circ} 48^{\prime} 32.0^{\prime \prime}$ & 2000 & 45 & 5 \\
\hline BSIA & La Paz & POO & $16^{\circ} 51^{\prime} 06.8^{\prime \prime}$ & $67^{\circ} 42^{\prime} 30.0^{\prime \prime}$ & 2040 & 4 & 0 \\
\hline BSIA & La Paz & *TUN 03 & $16^{\circ} 53^{\prime} 12.2^{\prime \prime}$ & $67^{\circ} 42^{\prime} 43.1^{\prime \prime}$ & 2095 & 20 & 6 \\
\hline BSIA & La Paz & ${ }^{*}$ QUE 01 & $17^{\circ} 01^{\prime} 54.8^{\prime \prime}$ & $67^{\circ} 40^{\prime} 38.6^{\prime \prime}$ & 2159 & 2 & 1 \\
\hline BSIA & La Paz & *VIZ 02 & $16^{\circ} 55^{\prime} 48.8^{\prime \prime}$ & $67^{\circ} 41^{\prime} 32.9^{\prime \prime}$ & 2182 & 78 & 8 \\
\hline BSIA & Cochabamba & BSIA 09 & $17^{\circ} 56^{\prime} 01.0^{\prime \prime}$ & $65^{\circ} 23^{\prime} 06.5^{\prime \prime}$ & 2182 & 1 & 0 \\
\hline BSIA & La Paz & ${ }^{*} \mathrm{CAC} 03$ & $17^{\circ} 00^{\prime} 30.1^{\prime \prime}$ & $67^{\circ} 39^{\prime} 25.2^{\prime \prime}$ & 2356 & 72 & 14 \\
\hline BSIA & La Paz & *TUN 02 & $16^{\circ} 43^{\prime} 11.5^{\prime \prime}$ & $67^{\circ} 52^{\prime} 25.7^{\prime \prime}$ & 2427 & 14 & 1 \\
\hline BSIA & La Paz & ${ }^{*} \mathrm{RUI} 01$ & $16^{\circ} 42^{\prime} 56.4^{\prime \prime}$ & $67^{\circ} 52^{\prime} 13.5^{\prime \prime}$ & 2459 & 7 & 1 \\
\hline BSIA & La Paz & *TUN 06 & $17^{\circ} 04^{\prime} 25.2^{\prime \prime}$ & $67^{\circ} 37^{\prime} 59.7^{\prime \prime}$ & 2493 & 5 & 3 \\
\hline BSIA & La Paz & BSIA 11 & $17^{\circ} 27^{\prime} 45.5^{\prime \prime}$ & $66^{\circ} 18^{\prime} 51.0^{\prime \prime}$ & 2543 & 3 & 0 \\
\hline BSIA & La Paz & *TUN 07 & $17^{\circ} 04^{\prime} 24.2^{\prime \prime}$ & $67^{\circ} 38^{\prime} 42.7^{\prime \prime}$ & 2543 & 1 & 1 \\
\hline BSIA & La Paz & *BSIA 12 & $17^{\circ} 03^{\prime} 34.8^{\prime \prime}$ & $67^{\circ} 39^{\prime} 58.4^{\prime \prime}$ & 2583 & 10 & 2 \\
\hline BSIA & Cochabamba & QUI & $17^{\circ} 25^{\prime} 20.0^{\prime \prime}$ & $66^{\circ} 17^{\prime} 40.0^{\prime \prime}$ & 2600 & 72 & 20 \\
\hline BSIA & La Paz & *LIE 01 & $17^{\circ} 04^{\prime} 44.6^{\prime \prime}$ & $67^{\circ} 37^{\prime} 57.0^{\prime \prime}$ & 2602 & 17 & 3 \\
\hline BSIA & La Paz & ${ }^{*} \mathrm{CAC} 02$ & $17^{\circ} 04^{\prime} 07.7^{\prime \prime}$ & $67^{\circ} 39^{\prime} 25.5^{\prime \prime}$ & 2645 & 5 & 1 \\
\hline BSIA & Cochabamba & BSIA 14 & $17^{\circ} 25^{\prime} 28.9^{\prime \prime}$ & $66^{\circ} 15^{\prime} 53.0^{\prime \prime}$ & 2689 & 33 & 7 \\
\hline BSIA & Cochabamba & CAC 04 & $17^{\circ} 28^{\prime} 37.5^{\prime \prime}$ & $66^{\circ} 08^{\prime} 16.1^{\prime \prime}$ & 2710 & 22 & 1 \\
\hline BSIA & La Paz & *TUN 01 & $16^{\circ} 42^{\prime} 25.4^{\prime \prime}$ & $67^{\circ} 59^{\prime} 37.6^{\prime \prime}$ & 2757 & 44 & 14 \\
\hline BSIA & La Paz & *BSIA 13 & $16^{\circ} 42^{\prime} 02.75^{\prime \prime}$ & $67^{\circ} 59^{\prime} 54.9^{\prime \prime}$ & 2765 & 6 & 1 \\
\hline BSIA & La Paz & *TUN 04 & $17^{\circ} 08^{\prime} 10.8^{\prime \prime}$ & $67^{\circ} 35^{\prime} 17.9^{\prime \prime}$ & 2767 & 5 & 1 \\
\hline BSIA & La Paz & *VIZ 01 & $16^{\circ} 41^{\prime} 25.4^{\prime \prime}$ & $68^{\circ} 00^{\prime} 39.7^{\prime \prime}$ & 2821 & 24 & 7 \\
\hline \multirow[t]{2}{*}{ BSIA } & La Paz & *TUN 05 & $17^{\circ} 07^{\prime} 32.0^{\prime \prime}$ & $67^{\circ} 35^{\prime} 59.5^{\prime \prime}$ & 2864 & 7 & 2 \\
\hline & & & & & Total BSIA & 554 & 118 \\
\hline PP & Potosi & VIS & $21^{\circ} 37^{\prime} 16.8^{\prime \prime}$ & $65^{\circ} 48^{\prime} 46.0^{\prime \prime}$ & 2963 & 10 & 7 \\
\hline \multirow[t]{2}{*}{ PP } & Potosi & TP 01 & $21^{\circ} 44^{\prime} 51.0^{\prime \prime}$ & $65^{\circ} 49^{\prime} 26.0^{\prime \prime}$ & 3080 & 34 & 19 \\
\hline & & & & & Total PP & 44 & 26 \\
\hline GC & Santa Cruz & SS-2 & $19^{\circ} 25^{\prime} 7.39^{\prime \prime}$ & $62^{\circ} 38^{\prime} 24.8^{\prime \prime}$ & 412 & 2 & 0 \\
\hline GC & Tarija & Z 01 & $21^{\circ} 50^{\prime} 48.2$ & $63^{\circ} 14^{\prime} 51.7^{\prime \prime}$ & 443 & 2 & 0 \\
\hline GC & Santa Cruz & SA & $20^{\circ} 13^{\prime} 42.4^{\prime \prime}$ & $62^{\circ} 54^{\prime} 2.4^{\prime \prime}$ & 553 & 7 & 0 \\
\hline GC & Santa Cruz & Z07 & $20^{\circ} 15^{\prime} 07.9^{\prime \prime}$ & $62^{\circ} 59^{\prime} 10.2^{\prime \prime}$ & 599 & 7 & 0 \\
\hline \multirow[t]{3}{*}{ GC } & Santa Cruz & Z08 & $20^{\circ} 11^{\prime} 02.6^{\prime \prime}$ & $63^{\circ} 01^{\prime} 21.5^{\prime \prime}$ & 614 & 2 & 0 \\
\hline & & & & & Total GC & 20 & 0 \\
\hline & & & & & Total general & 618 & 144 \\
\hline
\end{tabular}

* Results of these trapping sites were published in Buitrago et al. [8]

**The ecoregions are defined according to Ibisch et al. [19]; BSIA, Inter-Andean Dry Forest; PP, Prepuna; GC, Gran Chaco

essay (PCR-HDA). PCR amplification of a 355 bp Cytb fragment (PCR-Cytb) was achieved with the set of primers previously described in Lee et al. (2002) [23]. Amplification was performed in a thermocycler (Mastercycler, Eppendorf, Hamburg, Germany). Heteroduplex (HDA) chains subsequently formed were analysed by polyacrylamide gel electrophoresis according to Buitrago et al. (2012) [22] using human DNA as a driver.

\section{Sequencing of PCR products}

The direct sequencing of both strands of PCR products was performed by the company Macrogen (Seoul, Korea). 
Sequences of both strands were aligned using Clustal-W [24] provided in BioEdit version 7.2.0 [25], and corrected in case of any discrepancy by analysing the corresponding chromatograms. Sequences were trimmed to 235-319 bp and the search for the most similar sequences was done using Blast software (http://blast.ncbi.nlm.nih.gov/ Blast.cgi) in GenBank. The aim was to identify the genus and species of blood meal sources, based on the degree of sequence homology. Homology of $90 \%$ or more allows the genus and species of the blood meal source to be identified and below $90 \%$, only the genus.

\section{Results}

\section{Blood meal sources of wild $T$. infestans}

The intestinal contents of 618 wild T. infestans captured in Andean Dry Forests, Prepuna and Gran Chaco eco regions were processed. Positive PCR (meaning that DNA from a vertebrate was present) was obtained for 371 samples, and the blood meal sources were identified for 144 samples $(23.3 \%)$ (Table 1$)$. Multi-banding HDA patterns characteristic of multiple blood meal sources were observed for 32 other samples (8.6\%). The remaining 195 samples, including 10 from the Gran Chaco eco region, presented insufficient PCR products to obtain heteroduplex formation or for direct sequencing. The overall identified HDA patterns (144) were composed of two bands characteristic of the formation of the heteroduplex molecules. A total of 18 different heteroduplex patterns (P1 to P18) were identified. Seven of them plus two patterns of multiple banding are illustrated in Fig. 1.

To identify the species corresponding to the 18 different HDA patterns and their reproducibility, 59 PCR products were sequenced. After inference in GenBank with the Blast procedure, very high identity (98-100 \%) with sequences deposited in GenBank was generally obtained, allowing identification of blood meal sources at the species level (Table 2). The sequences corresponding to identical HDA patterns always had very high identity between them (98-100\%), and they best aligned with the same species in GenBank. However, sequences corresponding to different HDA patterns could also have sequences that best aligned with the same species in GenBank. This was detected for three species: (i) Octodontomys gliroides had two different HDA patterns (P1 and P6) whose corresponding sequences best aligned with different GenBank sequences of $O$. gliroides (Table 2). The similarity between these sequences was 99 \%; (ii) Galea musteloides had four different HDA patterns (P2, P7, P13 and P16) whose sequences best aligned with four different G. musteloides sequences deposited in GenBank. The similarity between the sequences of the patterns P16 and P7 was 96 and $99 \%$ between P2 and P13, but between the two groups the similarity reached only $78 \%$; (iii) Graomys domorum had three different HDA patterns (P8, P9 and P11) whose sequences were best aligned with one GenBank sequence of G. domorum; between two of these sequences the similarity was $99 \%$, while with the third sequence the similarity reached only $70 \%$.

Fourteen vertebrate species were identified as blood meal sources of wild $T$. infestans: 10 mammal species, two bird species, and two reptiles (Table 2). The most prevalent blood meal was O. gliroides (52/144, $36.6 \%$ ), a rodent of the family Octodontidae, indigenous to the Andes (Fig. 2). Seventy-three percent of these blood meal sources were detected in $2^{\text {nd }}$ to $5^{\text {th }}$ nymphal instars of wild $T$. infestans caught in the Inter-Andean Dry Forests and the Prepuna eco regions. The second most

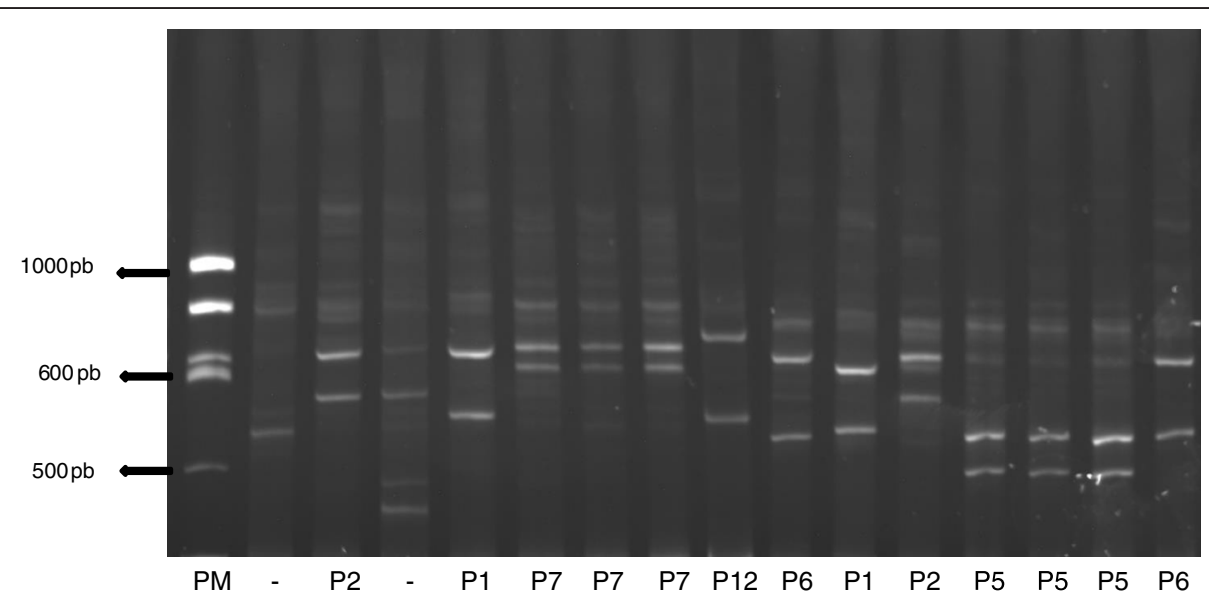

Fig. 1 Acrylamide electrophoresis gel showing PCR-HDA patterns of DNA samples obtained from intestinal contents of wild T. infestans: lane 1, molecular weight; lanes 3 and 12, P2 HDA pattern (G. musteloides); lanes 5 and 11, P1 HDA pattern (O. gliroides); lanes 6, 7 and 8, P7 HDA pattern (G. musteloides); lane 9, P12 HDA pattern (A. glaucinus); lanes 10 and 16, P6 HDA pattern (O. gliroides); lanes 13, 14 and 15, P5 HDA pattern (G. gallus); lanes 2 and 4, multibanding patterns corresponding to multiple meals 
Table 2 Sequencing and identification of blood meal sources of wild T. infestans with different patterns of HDA

\begin{tabular}{|c|c|c|c|c|c|c|}
\hline \multirow[t]{2}{*}{ Species } & \multirow[t]{2}{*}{ HDA patterns } & \multirow[t]{2}{*}{$\begin{array}{l}\text { Size of Cyt b } \\
\text { sequence }\end{array}$} & \multirow[t]{2}{*}{$\begin{array}{l}\text { No. of sequenced } \\
\text { PCR products }\end{array}$} & \multicolumn{3}{|l|}{$\begin{array}{l}\text { Results of the search for sequence identity } \\
\text { in GenBank }\end{array}$} \\
\hline & & & & Species with highest identity & GenBank: accession number & Identity (\%) \\
\hline \multirow[t]{16}{*}{ Mammal } & P3 & $315 \mathrm{bp}$ & 16 & Homo sapiens (human) & AY509658.1 & 99 \\
\hline & P1 & $289 \mathrm{bp}$ & 6 & Octodontomys gliroides (rodent) & AF370706.1 & 98 \\
\hline & P6 & $290 \mathrm{bp}$ & 6 & Octodontomys gliroides (rodent) & GQ121127.1 & 99 \\
\hline & P2 & $264 \mathrm{bp}$ & 3 & Galea musteloides (rodent) & GU067494.1 & $99-100$ \\
\hline & P7 & $264 \mathrm{bp}$ & 3 & Galea musteloides (rodent) & GU067530.1 & 100 \\
\hline & P13 & $235 \mathrm{bp}$ & 1 & Galea musteloides (rodent) & GU067494.1 & 99 \\
\hline & P16 & $235 \mathrm{bp}$ & 1 & Galea musteloides (rodent) & GU067513.1 & 100 \\
\hline & P4 & $255 \mathrm{bp}$ & 5 & Lagidium viscacia (rodent) & AY 254887.1 & 99 \\
\hline & P8 & $280 \mathrm{bp}$ & 1 & Graomys s.p. (rodent) & AF159291.1 & 88 \\
\hline & P9 & $290 \mathrm{bp}$ & 1 & Graomys domorum (rodent) & AF159291.1 & 99 \\
\hline & P11 & $287 \mathrm{bp}$ & 1 & Graomys domorum (rodent) & AF159291.1 & 99 \\
\hline & P12 & $319 \mathrm{bp}$ & 1 & Akodon glaucinus (rodent) & KC841384.1 & 95 \\
\hline & P10 & $310 \mathrm{bp}$ & 1 & Equus asinus (donkey) & FJ428527.1 & $92-99$ \\
\hline & P14 & $300 \mathrm{bp}$ & 1 & Felis catus (cat) & AY509646.1 & 99 \\
\hline & P15 & $290 \mathrm{bp}$ & 1 & Phyllotis wolffshoni (rodent) & AY956698.1 & 98 \\
\hline & P17 & $230 \mathrm{bp}$ & 2 & Phyllotis xantophigus chiliensis (rodent) & AY341053.1 & $96-99$ \\
\hline \multirow[t]{2}{*}{ Bird } & P18 & 322 bp & 1 & Subligatus modestus & AF447623.2 & 100 \\
\hline & P5 & $281 \mathrm{bp}$ & 6 & Gallus gallus (chicken) & EU 839454.1 & 100 \\
\hline \multirow[t]{2}{*}{ Reptile } & Absent $^{a}$ & $285 \mathrm{bp}$ & 1 & Tropidurus s.p. (lizard) & EF616030.1 & 89 \\
\hline & Absent ${ }^{a}$ & $294 \mathrm{bp}$ & 1 & Gymnodactylus s.p. (lizard) & AY630397.1 & 83 \\
\hline
\end{tabular}

${ }^{a}$ without profile

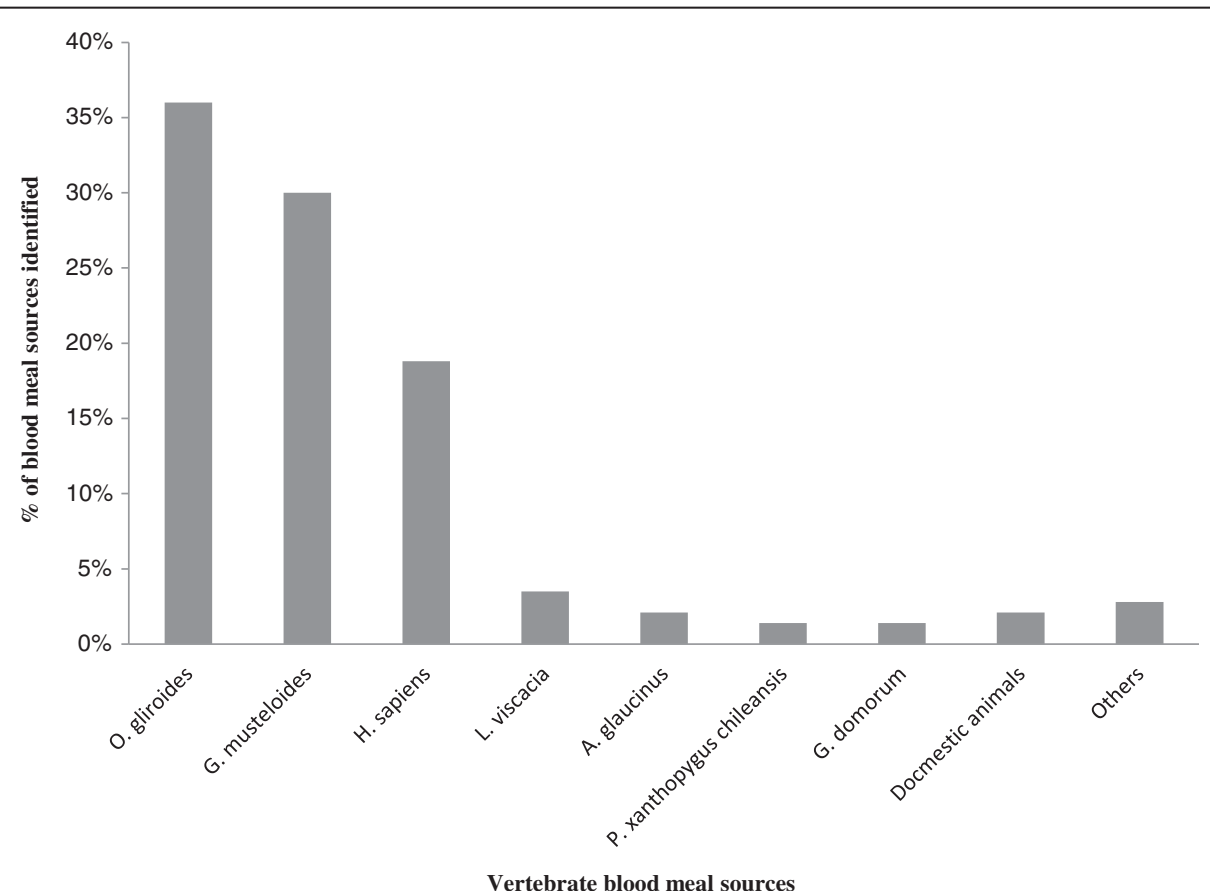

Fig. 2 Vertebrate blood sources of wild T. infestans identified by PCR-HDA and sequencing 
prevalent species was G. musteloides (43/144, $30.5 \%$ ), a rodent of the family Caviidae. Sixty-eight percent of these blood meal sources were identified in $3^{\text {rd }}$ to $5^{\text {th }}$ nymphal instars. The third most prevalent species was Homo sapiens (27/144, $18.7 \%)$, as previously detailed in Buitrago et al. (2013) [17]. Most of the human blood meals (66.7 \%) were identified in $2^{\text {nd }}$ to $5^{\text {th }}$ nymphal instars captured in areas close to $(50-200 \mathrm{~m})$ or more distant from $(\sim 400-800 \mathrm{~m})$ human habitation, in various ecotopes such as sedimentary cracks surrounded by fields of crops, prickly pear fields, sedimentary cliffs and rocky outcrops. The other identified blood meal sources included viscacha (Lagidium viscacia), four other rodent species, one species of wild bird and three species of domestic animals in $4^{\text {th }}$ nymphal instars (a donkey at $50 \mathrm{~m}$ from the human habitat, a cat at $120 \mathrm{~m}$ and a chicken at $200 \mathrm{~m}$ ) (Table 2, Fig. 2).

\section{Blood meal sources of wild and intra-peridomestic $T$. infestans in three specific areas Sapini}

In the sylvatic area around Sapini, 50 intestinal contents were processed and 17 blood meal sources (34 \%) were identified. Three species of wild rodents and human were identified (Table 3). The most prevalent blood meal source identified in both adult specimens and nymphal instars was $O$. gliroides $(58.8 \%$ ). The second most prevalent species was $H$. sapiens (23.5 \%) found in three adult specimens and a $5^{\text {th }}$ nymphal instar. In peridomiciles, a total of 13 samples were processed and the blood meal sources of seven samples were identified $(53.8 \%)$. The most prevalent blood sources were chicken $(71 \%)$ and human (Table 3, Fig. 3).

\section{Thago Thago}

From the sample collected in the wilderness of Thago Thago, 45 intestinal contents were processed but only five blood meal sources $(11 \%)$ were successfully identified: a species of wild rodent, human, chicken, and two lizards were found in $2^{\text {nd }}$ to $4^{\text {th }}$ nymphal instars (Table 3 ). In peridomiciles, a total of 71 samples were processed and 27 blood meal sources were identified (38 \%): three species of domestic animals, two species of wild animals, asynanthropic species of rodent and humans. The two most prevalent species were goat $(48 \%)$ and chickens $(26 \%)$ raised by the inhabitants of the area. It is worth noting that two species of wild animals were also identified: $O$. gliroides found in one T. infestans adult and Oryctolagus cuniculus in $3^{\text {rd }}$ and $4^{\text {th }}$ nymphal instars (Table 3, Fig. 3).

Table 3 Identification of blood meal sources of wild and peridomestic T. infestans in three localities in the Inter-Andean Dry Forest ecoregion

\begin{tabular}{|c|c|c|c|c|c|c|}
\hline \multirow[b]{3}{*}{ Blood meal source } & \multicolumn{6}{|c|}{ Locality and ecotope } \\
\hline & \multicolumn{2}{|c|}{ Sapini } & \multicolumn{2}{|c|}{ Thago Thago } & \multicolumn{2}{|c|}{ Quillacollo } \\
\hline & Wild & Peridomestic & Wild & Peridomestic & Wild & Peridomestic \\
\hline Akodon glaucinus (rodent) & & & & & 3 & \\
\hline Canis lupus (dog) & & & & & & 1 \\
\hline Capra hircus (goat) & & & & 13 & & \\
\hline Galea musteloides (rodent) & & & & & 14 & 20 \\
\hline Gallus gallus (hen) & & 5 & 1 & 7 & & 81 \\
\hline Graomys domorum (rodent) & & & 1 & & & \\
\hline Gymnodactylus s.p. (lizard) & & & 1 & & & \\
\hline Homo sapiens (human) & 4 & 2 & 1 & 1 & 2 & 7 \\
\hline Leiolopisma s.p. (lizard) & & & & & & 1 \\
\hline Maleagris gallopavo (poultry) & & & & & & 1 \\
\hline Octodontomys gliroides (rodent) & 10 & & & 1 & & \\
\hline Oryctolagus cuniculus (rabbit) & & & & 2 & & \\
\hline Ovis aries (sheep) & & & & 1 & & \\
\hline Phyllotis wolffsohni (rodent) & & & & & 1 & \\
\hline Phyllotis xanthopygus chileansis (rodent) & 2 & & & & & \\
\hline Rattus rattus (rodent) & & & & 1 & & 9 \\
\hline Sublegatus modestus (bird) & 1 & & & & & \\
\hline Sus scrofa (pig) & & & & 1 & & 9 \\
\hline Tropidurus s.p. (lizard) & & & 1 & & & \\
\hline Total & 17 & 7 & 5 & 27 & 20 & 129 \\
\hline
\end{tabular}




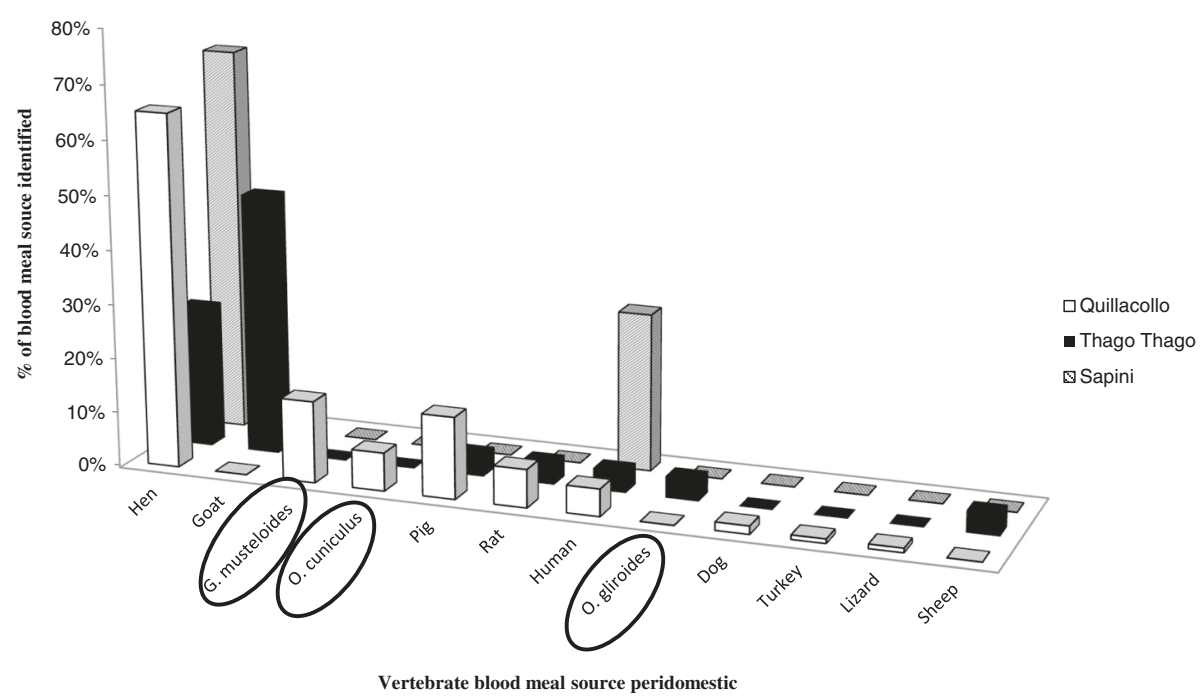

Fig. 3 Vertebrate blood meal sources of intra-peridomestic T. infestans identified by PCR-HDA and sequencing in three specific areas (Quillacollo, Thago Thago and Sapini). The ellipses show the wild animals identified

\section{Quillacollo}

From the sample collected in the wilderness of Quillacollo, 72 intestinal contents were processed and 20 blood meal sources $(27.8 \%)$ were identified. Three species of wild rodents and human were identified in adults and nymphal instars (Table 3). The most prevalent species was G. musteloides, which represented $70 \%$ of the blood meal sources, identified in three adults and two nymphal instars. In peridomiciles, a total of 196 samples were processed and 130 blood meal sources (66\%) were identified. The blood meal sources identified were three species of domestic animals, one species of wild animal, one species of synanthropic rodent, one lizard and human. The most prevalent species was chicken (41\%). The wild rodent G. musteloides accounted for $10 \%$ of the identified blood meal sources, and Rattus rattus, 4.5 \% (Table 3, Fig. 3).

\section{Discussion}

\section{Wild areas}

This study (together with the preliminary data we recently published, see $[17,22])$, is the first to study the molecular identification of blood meal sources of wild populations of $T$. infestans. The results indicate that wild T. infestans pose an epidemiological threat to humans in Bolivia since human blood was identified in $18.7 \%$ of the bugs tested, and also suggest the occurrence of two phenomena: (i) displacement of $T$. infestans from the human habitat to the wild after feeding, and (ii) exposure of humans to bites of T. infestans in the wild during their regular activities. Furthermore, the discovery of three wild $4^{\text {th }}$ nymphal instars of $T$. infestans with blood from domestic animals (donkey, cat, and chicken at 50, 120 , and $200 \mathrm{~m}$, from the closer peridomicile, respectively) suggests that wild $T$. infestans feed on domestic animals when these animals circulate in close wild environment. As previously shown through population genetics of $T$. infestans [15], the present observations support the connectivity between wild and domestic cycles and it constitutes a danger to human health with infection rates by $T$. cruzi reported from $3.8 \%$ in first nymphal instar to $85.7 \%$ in adult insects [8]. Other wild triatomine species have been found with human blood meal, such as Mepraia spinolai captured in a suburban neighbourhood of Santiago de Chile [26]. Thirty-eight percent of wild Triatoma rubida and Triatoma protracta captured in hills in the US were also found to have fed on humans [27]. In Colombia, human blood meals were identified in the strictly wild species Eratyrus cuspidatus. Recently, a mixture of human and opossum blood was identified in wild Triatoma dimidiata and a mixture of human and chicken blood was identified in Rhodnius pallencens captured in palm trees [28].

Fourteen different vertebrate blood sources, including reptiles, were identified in wild $T$. infestans. This supports the theory of opportunistic feeding habits for $T$. infestans, as already observed in many species $[29,30]$. In general, it was found that wild $T$. infestans had little intestinal content, and the percentage of identification was low because the blood source DNAs were probably degraded. Together these results may suggest that in the wilderness of the study area, there is little availability of food, forcing triatomines to search for multiple sources of food. The low blood host availability in the wilderness might also explain the identification of reptiles as blood 
sources of wild T. infestans. Indeed, a study carried out on food preferences in three triatomine species including T. infestans in laboratory conditions showed that this species seems more attracted to warm-blooded animals [31]. Nevertheless, even if the low accessibility of blood sources in the wilderness could explain the identification of reptiles as blood sources, this hypothesis is not well supported if we take into account results reported in other works performed with domesticated populations of triatomines. These results reported frequent multiple blood meals [32] and a species of frog (cold blood vertebrate) was also reported as the main feeding source [30].

In the current study, the proportion of multiple blood meals $(8.6 \%)$ in the wild triatomines was not that high compared with other studies. This could be explained by low accessibility to blood sources in the wilderness as already mentioned, which means scarcity of mammals in this area. Also this can be due to the low diversity of the mammal species, but unfortunately data on species and abundance of mammals in this region are not available. Another explanation can be the technique used, the current one could be less sensitive than the immuno diffusion test used before for T. longipennis populations $[32,33]$ and cloning followed by a recently developed sequencing technique $[27,30]$.

The predominant blood meal source identified is $O$. gliroides, a rodent endemic to the Andes. This rodent has been found to be infected with $T$. cruzi in a study northwest of Argentina, in Pucara, an archaeological area currently uninhabited close to Jujuy [34]. This suggests that this species could be a reservoir of $T$. cruzi and that it is an important species for the development of wild colonies of T. infestans in Bolivia.

G. musteloides is the second most important blood meal source identified as sustaining wild T. infestans. In 2006 and 2007 in a study in Quillacollo (Cochabamba, Bolivia), this mammal was associated with wild populations of T. infestans [7, 16]. Recently, Torrico et al. (2013) [35], conducted a study to isolate kinetoplastid protozoan from wild mammals in three departments of Bolivia (Cochabamba, Santa Cruz and Potosí). They found nine specimens of G. musteloides infected with T. cruzi in Cochabamba; they also found one infected specimen of G. domorum, a species that also constitutes a food source for wild $T$. infestans.

Interestingly, L. viscacia (vizcacha) was also identified as a blood meal source, confirming previous suggestions [8]. This small Andean mammal that looks similar to a rabbit is well-accustomed to rocky habitats. With regards to intraspecific variability found by PCR-HDA in G. musteloides where more than $10 \%$ sequence divergence was observed, as previously discussed, the presence of different species and not intraspecific variation is more likely [22]. In fact there is still no taxonomic consensus within the genus Galea [36].

\section{Specific inhabited areas and surroundings}

The simultaneous analysis of the blood meal sources of triatomines collected in the wild and in the corresponding peridomestic areas provided valuable information on the behaviour of insect vectors in the context of vectorhost interactions. Populations of wild triatomines are generally found to feed on a variety of wild mammals while resident species are found to feed on domestic animals. These assertions are widely supported by studies reporting chickens, humans, dogs and cats as the main blood meal sources of non-wild triatomines, including $T$. infestans, $T$. sordida, $T$. longipennis and $T$. dimidiata [5, 32, 33, 37, 38]. Our data largely confirmed these observations. Chickens were identified as the main blood meal sources in Sapini and Quillacollo and goats in Thago Thago where breeding goats is common. The blood meal sources identified generally corresponded to animals we observed occupying the capture sites. However, we must also emphasize that wild animals (O. gliroides, O. cuniculus and G. musteloides) were also identified as blood sources for the triatomines collected in the peridomiciles of Quillacollo and Thago Thago. These blood meal sources were identified mainly in $3^{\text {rd }}$ to $5^{\text {th }}$ nymphal instars $(72.7 \%)$ and therefore less likely to spread into the wild and return to the peridomicile. Consequently, in this specific case, these data suggest the movement of wild animals to the peridomicile. Similarly, both phenomena possibly occur at the same time. These animals circulating among wild and domestic habitats play a particular epidemiological role because they link the sylvatic cycle of the parasite with a domestic one.

In the same way, synanthropic animals such as rats also constituted an important blood meal source in the peridomiciliary area. In Quillacollo and Thago Thago, $R$. rattus represented 7 and $4 \%$ of the identified blood meal sources, respectively. Similarly, in a study in Mexico, $R$. rattus has been reported as the main blood meal source of Triatoma longipennis in peridomiciliary areas [32]. As an important blood meal source for triatomines, these synanthropic animals contribute to maintaining large triatomine populations near human dwellings.

\section{Conclusion}

In Bolivia and other South American countries, $T$. infestans is the target of large-scale campaigns of vector control based on insecticide spraying. The current study suggests that wild $T$. infestans attacks humans in the wild, but is also able to bite humans in domestic settings before going back to its natural environment. The link between the wild and domestic cycles 
of $T$. cruzi transmission is a danger to human health. The persistent re-infestation of houses by this species in the Andean region can be attributed, at least in part, to the dispersal of bugs from sylvatic populations, this statement is supported by genetic studies showing an absence of significant genetic differentiation between domestic populations and nearby sylvatic ones [15]. Together with the former study, our study suggests that wild populations of $T$. infestans are hindering control efforts in Bolivia and need to be taken into account in vector control strategies. While insecticide spraying may be effective for the control of triatomine populations that are well established inside dwellings, the dispersal of $T$. infestans from the wild environment makes vector control challenging. Consequently, for the control of $T$. infestans, the use of other strategies (such as the use of window screens) together with insecticide spraying will be needed in areas where wild populations of this species exist $[39,40]$.

\section{Competing interests}

The authors declare that they have no competing interests.

\section{Authors' contributions}

Designed the study (SFB, MFB, ), participated in field work (RB, RS, EW, CA, $\mathrm{SD}, \mathrm{MFB}, \mathrm{CB}, \mathrm{SFB}$ ), computed data ( RB, SFB), analyzed data (RB, SFB), wrote the manuscript (RB, SFB,), contributed significantly to the corrections of the manuscript (EW, SD CB). All authors read and approved the final version of the manuscript.

\section{Acknowledgments}

We are particularly grateful to the direction of the INLASA (Instituto de Laboratorios de Salud, La Paz Bolivia), Dr. José Raphael Gutiérrez and Dr. Walter Agreda to have hosted this work in the Department of Medical Entomology directed by Dr. Tamara Chavez. We also thank Natalie Wickenkamp for collaborating with the English review. This study received financial supports from the ANR (Agence Nationale de la Recherche, France), and the IRD (Institut de Recherche pour le Développement, France).

\section{Author details}

${ }^{1} \mathrm{IRD}$, Institut de Recherche pour le Développement, UMR INTERTRYP, (IRD-CIRAD), Interactions hôtes-vecteurs-parasites-environnement dans les maladies tropicales négligées dues aux trypanosomatidés, 911 Av. Agropolis, Montpellier, cédex 5 34394, France. ${ }^{2}$ Instituto Nacional de Laboratorios de Salud (INLASA), Laboratorio de Entomología Médica, Rafael Zubieta \#1889, Miraflores Casilla M-10019, La Paz, Bolivia.

\section{Received: 26 September 2015 Accepted: 6 April 2016}

Published online: 18 April 2016

\section{References}

1. Dias JC. Southern Cone Initiative for the elimination of domestic populations of Triatoma infestans and the interruption of transfusional Chagas disease. Historical aspects, present situation, and perspectives. Mem Inst Oswaldo Cruz. 2007;1:11-8.

2. Torrico RA. Hallazgo de Eratyrus mucronatus, infestación natural de vinchucas de cerro y Eutriatoma sordida en Cochabamba. Lab Central Cochabamba. 1946;1:19-23.

3. Dujardin JP, Tibayrenc M, Venegas E, Maldonado L, Desjeux P, Ayala FJ. Isozyme evidence of lack of speciation between wild and domestic Triatoma infestans (Heteroptera: Reduviidae) in Bolivia. J Med Entomol. 1987;24(1):40-5.
4. Bermudez H, Balderrama F, Torrico F. Identification and characterization of sylvatic foci of Triatoma infestans in central Bolivia. Am J Trop Med Hyg. 1993:49:371

5. Noireau F, Flores R, Gutierrez T, Dujardin JP. Detection of sylvatic dark morphs of Triatoma infestans in the Bolivian Chaco. Mem Inst Oswaldo Cruz. 1997;92(5):583-4.

6. Noireau F, Bastrenta B, Catalá S, Dujardin JP, Panzera F, Torres M, Perez R, Galvão C, Jurberg J. Sylvatic population of Triatoma infestans from the Bolivian Chaco: from field collection to characterization. Mem Inst Oswaldo Cruz. 2000;95(1):119-22.

7. Cortez MR, Emperaire L, Piccinali RV, Gürtler RE, Torrico F, Jansen AM, Noireau F. Sylvatic Triatoma infestans (Reduviidae, Triatominae) in the Andean valleys of Bolivia. Acta Trop. 2007a; 102(1):47-54.

8. Buitrago R, Waleckx E, Bosseno MF, Zoveda F, Vidaurre P, Salas R, Mamani E, Noireau F, Brenière SF. First report of widespread wild populations of Triatoma infestans (Reduviidae, Triatominae) in the valleys of La Paz, Bolivia. Am J Trop Med Hyg. 2010;82(4):574-9.

9. Waleckx E, Salas R, Huamán N, Buitrago R, Bosseno MF, Aliaga C, Barnabé C, Rodriguez R, Zoveda F, Monje M, Baune M, Quisberth S, Villena E, Kengne P, Noireau F, Brenière SF. New insights on the Chagas disease main vector Triatoma infestans (Reduviidae, Triatominae) brought by the genetic analysis of Bolivian sylvatic populations. Infect Genet Evol. 2011;11(5):1045-57.

10. Waleckx E, Depickère S, Salas R, Aliaga C, Monje M, Calle H, Buitrago R, Noireau F, Brenière SF. New discoveries of sylvatic Triatoma infestans (Hemiptera: Reduviidae) throughout the Bolivian Chaco. Am J Trop Med Hyg. 2012;86(3):455-8.

11. Brenière $S F$, Barnabé $C$, Brémond $P$, Buitrago R. Sistema vectorial emergente debido a las poblaciones salvajes de Triatoma infestans: la enfermedad de Chagas en Bolivia, proyecto TiBo. BIOFARBO. 2012;20(1):1-7.

12. Bacigalupo A, Torres-Pérez F, Segovia V, García A, Correa JP, Moreno L, Arroyo P, Cattan PE. Sylvatic foci of the Chagas disease vector Triatoma infestans in Chile: description of a new focus and challenges for control programs. Mem Inst Oswaldo Cruz. 2010;105(5):633-41.

13. Ceballos LA, Piccinali RV, Marcet PL, Vazquez-Prokopec GM, Cardinal MV, Schachter-Broide J, Dujardin JP, Dotson EM, Kitron U, Gürtler RE. Hidden sylvatic foci of the main vector of Chagas disease Triatoma infestans: threats to the vector elimination campaign? PLoS Negl Trop Dis. 2011;5(10):e1365.

14. Rolón M, Vega MC, Román F, Gómez A, Rojas de Arias A. First report of colonies of sylvatic Triatoma infestans (Hemiptera: Reduviidae) in the Paraguayan Chaco,using a trained dog. PLoS Negl Trop Dis. 2011:5(5):e1026.

15. Brenière SF, Salas R, Buitrago R, Brémond P, Sosa V, Bosseno MF, Waleckx E, Depickère $S$, Barnabé C. Wild populations of Triatoma infestans are highly connected to intra-peridomestic conspecific populations in the Bolivian Andes. PLoS One. 2013;8(11):e80786.

16. Cortez MR, Pinho AP, Cuervo P, Alfaro F, Solano M, Xavier SC, D'Andrea PS, Fernandes O, Torrico F, Noireau F, Jansen AM. Trypanosoma cruzi (KinetoplastidaTrypanosomatidae): ecology of the transmission cycle in the wild environment of the Andean valley of Cochabamba, Bolivia. Exp Parasitol. 2006:114(4):305-13.

17. Buitrago NL, Bosseno MF, Waleckx E, Brémond P, Vidaurre P, Zoveda F, Brenière SF. Risk of transmission of Trypanosoma cruzi by wild Triatoma infestans (Hemiptera: Reduviidae) in Bolivia supported by the detection of human blood. Infect Genet Evol. 2013;19:141-4.

18. Cortez M, Avalos M, Rocha V, Gorla D. Distribución biogeográfica de los tritaminos en Bolivia: discriminación de la distribución de las especies en relación a variables ambientales. In: Cortez MR, editor. Triatominos de Bolivia y la enfermedad de Chagas: Ministerio de Salud y Deportes. Bolivia: Programa Nacional de Chagas, 2007b. p. 97.

19. Ibisch PL BS, Gerckmann B, Carretero A. La Diversidad biologica. In: Ibisch PL, Mérida G, editors. Biodiversidad: la riqueza de Bolivia Estado de conocimiento y conservacion. Santa Cruz de la Sierra: FAN Bolivia; 2008. pp. 47-88.

20. Noireau F, Abad-Franch F, Valente SA, Dias-Lima A, Lopes CM, Cunha V, Valente VC, Palomeque FS, de Carvalho-Pinto CJ, Sherlock I, Aguilar M, Steindel M, Grisard EC, Jurberg J. Trapping Triatominae in silvatic habitats. Mem Inst Oswaldo Cruz. 2002;97(1):61-3.

21. Lent H, Wygodzinsky P. Revision of the Triatominae (Hemiptera:Reduviidae), and their significance as vectors of Chagas disease. Bull Am Mus Nat Hist. 1979;163:125-520. 
22. Buitrago R, Depickère S, Bosseno MF, Patzi ES, Waleckx E, Salas R, Aliaga C, Brenière SF. Combination of cytochrome $b$ heteroduplex-assay and sequencing for identification of triatomine blood meals. Infect Genet Evol. 2012:12(1):21-7.

23. Lee JH, Hassan H, Hill G, Cupp EW, Higazi TB, Mitchell CJ, Godsey MS Jr, Unnasch TR. Identification of mosquito avian-derived blood meals by polymerase chain reaction-heteroduplex analysis. Am J Trop Med Hyg 2002;66(5):599-604.

24. Thompson JD, Higgins DG, Gibson TJ. CLUSTAL W: improving the sensitivity of progressive multiple sequence alignment through sequence weighting position-specific gap penalties and weight matrix choice. Nucleic Acids Res. 1994;22(22):4673-80.

25. Hall TA. BioEdit: a user-friendly biological sequence alignment editor and analysis program for Windows 95/98/NT. Nucleic Acids Symp Ser. 1999:41:95-8.

26. Canals M, Cruzat L, Molina MC, Ferreira A, Cattan PE. Blood host sources of Mepraia spinolai (Heteroptera: Reduviidae), wild vector of Chagas disease in Chile. J Med Entomol. 2001;38(2):303-7.

27. Stevens L, Dorn PL, Hobson J, de la Rua NM, Lucero DE, Klotz JH, Schmidt JO, Klotz SA. Vector blood meals and Chagas disease transmission potential, United States. Emerg Infect Dis. 2012;18(4):646-9.

28. Peña VH, Fernández GJ, Gómez-Palacio AM, Mejía-Jaramillo AM, Cantillo O, Triana-Chávez O. High-resolution melting (HRM) of the cytochrome b gene: a powerful approach to identify blood-meal sources in Chagas disease Vectors. PLoS Negl Trop Dis. 2012;6(2):e1530.

29. Rabinovich JE, Kitron UD, Obed Y, Yoshioka M, Gottdenker N, Chaves LF. Ecological patterns of blood-feeding by kissing-bugs (Hemiptera: Reduviidae: Triatominae). Mem Inst Oswaldo Cruz. 2011;106(4):479-94.

30. Waleckx E, Suarez J, Richards B, Dorn PL. Triatoma sanguisuga blood meals and potential for Chagas disease, Louisiana, USA. Emerg Infect Dis. 2014;20(12):2141-3.

31. Jirón LF, Zeledón R. Preferencias alimentarias de tres especies de Triatominae (Hemiptera: Reduvüdae) en condiciones experimentales. Rev Biol Trop. 1982;30(2):151-59.

32. Brenière F, Pietrokovsky S, Magallón E, Bosseno MF, Soto MM, Ouaissi A, Lozano F, Wisneveski-colli C. Feeding patterns of Triatoma longipennis Usinger (Hemiptera Reduviidae) in Peridomestic habitats of rural community in Jalisco State. Mexico. J Med Entomol. 2004;41(6):1015-20.

33. Bosseno MF, García LS, Baunaure F, Gastelúm EM, Gutierrez MS, Kasten FL, Dumonteil $E$, Brenière SF. Identification in triatomine vectors of feeding sources and Trypanosoma cruzi variants by heteroduplex assay and a multiplex miniexon polymerase chain reaction. Am J Trop Med Hyg. 2006;74(2):303-5.

34. Schweigmann NJ, Alberti A, Pietrokovsky S, Conti O, Riarte A, Montoya S, Wisnivesky-Colli C. A new host of Trypanosoma cruzi from Jujuy, Argentina: Octodontomys gliroides (Gervais \& D'Orbigny, 1844) (Rodentia, Octodontidae). Mem Inst Oswaldo Cruz. 1992;87(2):217-20.

35. Torrico MC, Téllez T, Tenorio O, Rojas L, Huaranca JC, De la Barra A, García AL, Torrico F. Tripanosomátidos aislados de mamíferos silvestres en tres departamentos de Bolivia (Cochabamba, Potosí y Santa Cruz de la Sierra). Gac Med Bol. 2013;36(1):6-10.

36. Dunnum J, Salazar-Bravo J. Phylogeny, evolution, and systematics of the Galea musteloides complex (Rodentia: Caviidae). J Mammal. 2010;91:243-59.

37. Fernandes AJ, Chiari E, Casanova C, Dias JC, Romanha AJ. The threat of reintroduction of natural transmission of Chagas' disease in Bambuí, Minas Gerais State, Brazil, due to Panstrongylus megistus. Mem Inst Oswaldo Cruz. 1992;87(2):285-9.

38. Gurtler RE, Cecere MC, Vazquez DP, Chuit R, Cohen JE. Host-feeding patterns of domiciliary Triatoma infestans (Hemiptera: Reduviidae) in Northwest Argentina: seasonal and instar variation. J Med Entomol. 1996;33(1):15-26.

39. Waleckx E, Gourbière S, Dumonteil E. Intrusive versus domiciliated triatomines and the challenge of adapting vector control practices against Chagas disease. Mem Inst Oswaldo Cruz. 2015a; 110 (3): 324-38.

40. Waleckx E, Camara-Mejia J, Ramirez-Sierra MJ, Cruz-Chan V, Rosado-Vallado M,Vazquez-Narvaez S, Najera-Vazquez R, Gourbière S, Dumonteil E. An innovative ecohealth intervention for Chagas disease vector control in Yucatan, Mexico. Trans R Soc Trop Med Hyg. 2015b; 109 (2):143-9.

\section{Submit your next manuscript to BioMed Central and we will help you at every step:}

- We accept pre-submission inquiries

- Our selector tool helps you to find the most relevant journal

- We provide round the clock customer support

- Convenient online submission

- Thorough peer review

- Inclusion in PubMed and all major indexing services

- Maximum visibility for your research

Submit your manuscript at www.biomedcentral.com/submit
() BioMed Central 